\title{
Superovulation of Cows with PMSG: Variation in Plasma Concentrations of Progesterone, Oestradiol, LH, Cortisol, Prolactin and PMSG and in Number of Preovulatory Follicles
}

\author{
M.M. BEVERS and S.J. DIELEMAN \\ Clinic for Veterinary Obstetrics, A.I. and Reproduction, Veterinary Faculty, State University of \\ Utrecht, Yalelaan 7, 3508 TD Utrecht (The Netherlands)
}

(Accepted 22 July 1987)

\begin{abstract}
Bevers, M.M. and Dieleman, S.J., 1987. Superovulation of cows with PMSG: variation in plasma concentrations of progesterone, oestradiol, LH, cortisol, prolactin and PMSG and in number of preovulatory follicles. Anim. Reprod. Sci., 15: 37-52.
\end{abstract}

Forty-two heifers, exhibiting normal oestrous cycles, were treated with 2500 I.U. PMSG and 2 $\mathrm{ml}$ prostaglandin (PG) at day 10 and 12 of the oestrous cycle, respectively. In ten heifers progesterone, oestradiol, LH, prolactin, cortisol and PMSG levels were estimated until 10 days after the initiation of superovulation. In 32 heifers the occurrence of the LH surge was determined with a rapid radioimmunoassay, and $22-30 \mathrm{~h}$ after the $\mathrm{LH}$ surge the heifers were ovariectomized. The numbers of large follicles $(>10 \mathrm{~mm})$ and ovulations on the collected ovaries were counted and the levels of progesterone, oestradiol, PMSG and LH in the peripheral blood where estimated. The sum of large follicles and ovulations was assumed to represent the number of preovulatory follicles. In $16.7 \%$ of the heifers no LH surge was detected. This failure of the LH surge after superovulation appeared not to be caused by significantly different levels of cortisol, prolactin and PMSG as compared to those of cows responding with an LH surge.

There was quite some variability in the interval between the PG injection and the maximum of the LH surge. The mean interval was $43.9 \pm 1.5 \mathrm{~h}$ (SEM; $n=28$ ). This interval PG-LH was negatively correlated with the number of preovulatory follicles $(r=-0.483 ; P<0.01)$. The interval between the onset of oestrus and the maximum of the LH surge was $1.96 \pm 0.54 \mathrm{~h}(n=22)$.

The oestradiol concentration during the preovulatory LH surge and the number of preovulatory follicles were positively correlated $(r=0.732 ; P<0.01)$. Progesterone levels were significantly increased after the initiation of superovulation. There was no significant correlation between the progesterone level before or after the administration of PMSG and the number of preovulatory follicles. This number was also not correlated with the concentration of PMSG in the peripheral blood shortly after injection of PMSG or shortly after injection of PG. The results indicate that the marked variability in response to PMSG/PG superovulation is not due to variations of hormone concentrations during the stages of preovulatory follicular development. 


\section{INTRODUCTION}

The objective of superovulation is the enhancement of the yield of viable embryos by increasing the ovulation rate. Even under standard conditions with respect to breed, nutritional state of the animal and season, the use of gonadotrophic hormones such as PMSG or FSH causes a high variability in the number of good embryos collected. Part of the variation can be attributed to failures in the artificial insemination technique and/or the flushing techniques used to collect the embryos. However, the main cause may be found in the variation of the hormonal response of the animals after the initiation of the superovulation procedure.

Injection of PMSG during the mid-luteal phase of the oestrous cycle of the cow leads to a drastic increase of LH and FSH activity in the circulation for several days due to the long half-life of this glycoprotein. The consequence is often a second growth wave of follicles after ovulation, releasing high amounts of oestradiol into the blood.

Bouters et al. (1983) supposed that high concentrations of oestradiol may negatively affect the early embryonic development of the fertilized oocytes. The hypothesis was based on the observation that addition of an anti-PMSG serum after oestrus reduced the oestradiol levels and increased the number of viable embryos. However, the anti-PMSG serum also appeared to increase the number of corpora lutea. This would indicate that disturbances in the growth and the development of follicles and, as a consequence, in the maturation process of the oocytes may be the other cause of the variation seen after treatment with PMSG. Recently several studies on aspects of superovulation based on this assumption have been reported (Monniaux et al., 1984; Moor et al., 1984; Callesen et al., 1986).

Looking at follicular development after the administration of PMSG until ovulation, three stages can be distinguished in which disturbances or disorders may occur:

- the luteal period between the initiation of superovulation and the addition of prostaglandin ( $P G$ ). In this period, during which stage primary stimulation of follicular growth takes place, progesterone is markedly elevated due to the injection of PMSG (Saumande, 1980; Callesen et al., 1986).

- the period between the administration of $\mathrm{PG}$ and the appearance of the endogenous LH surge. It is at this second stage that follicles have to develop into follicles with preovulatory qualities; this period is often shortened compared to non-treated animals (Saumande, 1980; Callesen et al., 1986).

- the period between the endogenous LH surge and ovulation. During this third stage final follicular and oocyte maturation are completed; in normally cyclic cows these processes are guided by important chronological alterations of follicular steroid metabolism (Dieleman et al., 1983a, b; Dieleman and Blan- 
kenstein, 1984, 1985). In treated cows these processes take place in an environment of rather high FSH and LH activity due to PMSG.

This classification has been taken as a starting point in our investigations of the effect of PMSG treatment on follicular development. In the current report the peripheral blood concentrations of progesterone, oestradiol, LH, prolactin, cortisol and PMSG after the initiation of superovulation with PSMG were analysed and the interrelationships between these hormone levels and the growth and development of follicles, as characterized by the number of preovulatory follicles, were determined.

\section{MATERIALS AND METHODS}

\section{Animals}

The study was carried out in January 1985 with 10 Dutch-Friesian heifers (experiment 1) and from September 1985 to January 1986 with 32 Dutch-Friesian and Meuse-Rhine-Yssel heifers (experiment 2). After at least three observed normal oestrous cycles on pasture, the heifers were housed indoors in groups of eight animals under conditions which ensured normal ovarian cyclicity; this housing and detection of oestrus were as described previously (Dieleman et al., 1983a). The moment of first standing oestrus was regarded as the onset of oestrus. Experiments were started after at least one normal cycle indoors as determined by oestrous behaviour and pattern of the progesterone concentration in the peripheral blood.

\section{Experiment 1}

Ten heifers received 2500 I.U. PMSG i.m. (Folligon, Intervet International B.V., Boxmeer, The Netherlands) on day 10 at $08.00 \mathrm{~h}$ and $2 \mathrm{ml} \mathrm{PG} \mathrm{i.m.} \mathrm{(Pro-}$ solvin, Intervet International B.V.) on day 12 at $08.00 \mathrm{~h}$. Blood samples were collected as previously described (Dieleman et al., 1983a) once a day from day 0 until day 12 , then every $4 \mathrm{~h}$ until $17 \mathrm{~h}$ after the PG injection, then every $2 \mathrm{~h}$ for $48 \mathrm{~h}$ and finally every $6 \mathrm{~h}$ for 7 days. Oestrous detection after PMSG/PG treatment was not performed in these cows.

\section{Experiment 2}

Thirty-two heifers received 2500 I.U. PMSG i.m. (Folligon) on day 10 at $00.00 \mathrm{~h}$ and PG ( $2 \mathrm{ml}$ Prosolvin) on day 12 at $00.00 \mathrm{~h}$. Blood samples were collected once a day from day 0 until day 12 , then every $4 \mathrm{~h}$ until $24 \mathrm{~h}$ after the injection of $\mathrm{PG}$ and thereafter at hourly intervals until ovariectomy or until 60 $h$ after $P G$ and then every $6 h$ for 7 days. 


\section{Collection of ovaries}

The ovaries of 28 animals in experiment 2 were recovered by ovariectomy (Dieleman et al., 1983a) in the period of 22-30 h after the maximum of the LH surge, which is around the expected time of ovulation. The time of the LH surge was determined with a rapid radioimmunoassay (RIA) which was performed every hour from $30 \mathrm{~h}$ after the injection of $\mathrm{PG}$.

The number of large $(>10 \mathrm{~mm})$ follicles and of ovulations was determined and their sum was assumed to be the number of preovulatory follicles. Follicular fluid and tissues were collected for other studies on steroid-synthesizing ability and gonadotrophin-binding capacity.

The other four cows in experiment 2 were excluded from the experiments since the LH surge failed to appear before $60 \mathrm{~h}$ after PG; in normally cyclic heifers the interval between the onset of the regression of the corpus luteum and the onset of the LH surge is $58 \mathrm{~h}$ (Dieleman et al., 1986).

\section{Radioimmunoassays}

Concentrations of progesterone were estimated by a direct solid phase ${ }^{125} \mathrm{I}$ RIA method (Coat-A-Count TKPG; Diagnostic Products Corporation, Los Angeles, CA, U.S.A.) in 100- $\mu \mathrm{l}$ samples in duplicate according to the manufacturer. The main cross-reactivities were $2.4,2.0,1.7$ and $1.3 \%$ for deoxycortisol, $20 \alpha$-hydroxypregn-4-ene-3-one, deoxycorticosterone and $5 \beta$-pregnane-3,20dione, respectively, and $<1 \%$ for other steroids tested, according to the manufacturer. The sensitivity was $0.15 \mathrm{nmol} / \mathrm{l}$ and the interassay coefficient of variation was $11 \%(n=16)$. A correlation of $r=0.97(P<0.001)$ was observed for the comparison of the progesterone concentrations throughout the oestrous cycle of five cows as estimated by this RIA method with those as estimated by the method described previously (Dieleman and Schoenmakers, 1979; Dieleman et al., 1986).

Concentrations of oestradiol-17 $\beta$ were estimated by a solid phase ${ }^{125}$ I RIA method (Coat-A-Count TKE; Diagnostic Products Corporation) according to the manufacturer with slight modifications. Plasma samples of $1.0 \mathrm{ml}$ were extracted once with $2 \mathrm{ml}$ freshly opened diethylether (Analar quality; BDH, Poole, Great Britain ). After evaporation of the solvent under a nitrogen stream, the residue was dissolved in $250 \mu \mathrm{l} 0.02 \mathrm{M}$ borate buffer $(\mathrm{pH} 8.5$ in $0.9 \% \mathrm{NaCl}$ ) by sonification for $5 \mathrm{~min}$, and $100 \mu \mathrm{l}$ in duplicate were assayed. The recovery was established by extracting five parallel samples to which $10000 \mathrm{dpm}$ tritiated oestradiol had been added (mean recovery: $85.1 \pm 2.2$ (S.D.) \% for eight assays ). A standard curve of 3.7 to $231 \mathrm{fmol}$ was used. The main cross-reactivities were $1.1,0.32$ and $0.16 \%$ for oestrone, oestriol and oestradiol $-17 \alpha$ respectively, and $\ll 0.01$ for other steroids tested according to the manufacturer. The sensitivity was $7.5 \mathrm{pmol} / \mathrm{l}$ and the interassay coefficient of variation was $8.9 \%$ 
$(n=8)$. A correlation coefficient of $r=0.98(P<0.001)$ was observed for the comparison of the oestradiol concentrations $(n=50)$ as estimated by this RIA method with those estimated by the method described previously (Dieleman et al.,1986) .

Concentrations of cortisol were estimated by a direct solid phase ${ }^{125}$ I RIA method (Coat-A-Count TKCO; Diagnostic Products Corporation) in 25- $\mu$ l samples in duplicate according to the manufacturer. The main cross-reactivities were $1.5,1.4,1.3$ and $0.6 \%$ for deoxycorticosterone, corticosterone, deoxycortisol and cortisone, respectively, and $<02 \%$ for other steroids tested, according to the manufacturer. The sensitivity was $6 \mathrm{nmol} / \mathrm{l}$ and the interassay coefficient of variation was $10 \%(n=10)$. A correlation of $r=0.98(P<0.001)$ was observed for the comparison of the cortisol concentrations of 10 plasma samples as estimated by this RIA method with those as estimated by the method described previously (Dieleman et al., 1986).

LH and prolactin were estimated by previously validated RIA methods (Dieleman et al., 1983b, 1986). The intra- and interassay coefficients of variation were $<9$ and $<13 \%(n=25)$ respectively. The sensitivity, defined as the lowest detectable amount, was $0.4 \mu \mathrm{g} / \mathrm{l}$ NIH-LH-B4 and $0.1 \mathrm{bPRL}-20482 \mu \mathrm{g} / \mathrm{l}$ for the RIA of LH and prolactin, respectively. The standard bPRL-20482 was purified from freshly frozen bovine pituitaries according to the method described by Reichert (1975). Cross reaction of this preparation in the assay with the bovine NIH-P-B3 standard was $320 \%$. Cross-reaction of PMSG (PMSGPM23; a generous gift of Intervet International B.V.) in the LH-RIA with the standard NIH-LH-B4 was $<0.2 \%$.

For the rapid LH determination, samples were estimated in triplicate by a rapid solid phase RIA method using bovine bLH-7981, for iodination and standard curve, and the antiserum of the standard assay (Dieleman et al., 1983b). Briefly, to 100- $\mu \mathrm{l}$ samples and standards in antiserum-coated tubes, $800 \mu \mathrm{l} 0.01$ $M$ sodium phosphate buffered saline (PBS; pH 7.0) containing $1 \%$ bovine serum albumin (BSA; Sigma Chemical Company, St. Louis, MO, U.S.A.) and $0.05 \%$ sodium azide, and $100 \mu \mathrm{l}$ iodinated bLH-7981 were added. After incubation for $3 \mathrm{~h}$ at $37^{\circ} \mathrm{C}$ in a closed water bath, the liquid phase was thoroughly removed from the tubes which were then counted for $30 \mathrm{~s}$ in a two-detector gamma counter (Multi-Prias; Packard Instruments Company, Downers Grove, IL, U.S.A.). The polystyrene tubes (LP/3; Luckham Ltd., Burgess Hill, Sussex, Great Britain) were coated for at least $4 \mathrm{~h}$ at room temperature with $1 \mathrm{ml}$ antiserum diluted 1:10 000 in $0.05 \mathrm{M}$ sodium bicarbonate buffer ( $\mathrm{pH} \mathrm{9.0)}$ ), and washed twice with the $1 \%$ BSA PBS buffer; the tubes were stored at $-25^{\circ} \mathrm{C}$ in sealed plastic bags until RIA. This rapid RIA method allowed the LH concentration to be known within $4 \mathrm{~h}$ after taking a blood sample. The $\mathrm{LH}$ concentration of blood samples during the LH surge was also estimated afterwards by the standard assay for all animals, to validate the precision of the determination of the time when the maximum of the LH surge occurred. 
Comparison of the intervals between the $\mathrm{LH}$ peak and the time of ovariectomy as determined by the rapid and the standard assay produced the regression equation $Y=0.97 X+0.75(r=0.96 ; P<0.001)$.

All concentrations of PMSG were estimated in one assay with a homologous double antibody RIA. The antiserum raised in sheep (a generous gift of the late Professor Dr. R.A. Bouters, Veterinary Faculty, University of Ghent, Belgium) was used in a final dilution of 1:160 000. Purified PMSG (PMSG PM23$2 \mathrm{P}$, a generous gift of Intervet International B.V.) was used as standard and for iodination. Cross reaction of bovine NIH-LH-B4 and the purified bFSH preparation of Cheng (Cheng, 1978) was $\ll 0.1 \%$. The lowest detectable amount of PMSG in a plasma sample was $0.3 \mu \mathrm{g} / \mathrm{l}$ plasma. The intra-assay coefficient of variation was $7.1 \%(n=12)$ and the recovery was $97.1 \pm 2.7 \%$ (SEM; $n=10$ ).

\section{Statistics}

Student's $t$-test, or when appropriate the paired $t$-test, was used to compare the mean of two samples (two-tailed). Correlation was studied with the Spearman rank correlation test or, when appropriate, with linear regression analysis.

\section{RESULTS}

\section{Experiment 1}

After administration of 2500 I.U. PMSG on day 10 and $2 \mathrm{ml}$ PG on day 12, the heifers and their hormone profiles of progesterone and oestradiol were arranged into two groups on the basis of the presence (group A) or absence (group B) of a preovulatory LH surge. The profiles of a representative heifer of each group are depicted in Fig. 1A and B.

Group $A(n=7)$. The interval between the PG injection and the maximum of the LH surge varied considerably between the heifers; the mean time was $40.9 \pm 2.1$ (SEM) $\mathrm{h}$. This period is shortened compared to normally cyclic heifers in which the interval between the onset of luteal regression and the $\mathrm{LH}$ peak release measures $61 \mathrm{~h}$ (Dieleman et al., 1986).

The oestradiol concentration in the peripheral blood reached a maximum level at the time of the LH surge of $192 \pm 26 \mathrm{pmol} / \mathrm{l}$ and declined sharply thereafter in about $12 \mathrm{~h}$, similar to the patterns in normally cyclic cows (Dieleman et al., 1986). Subsequently, in 6 heifers, oestradiol was released in a second peak which started about $24 \mathrm{~h}$ after the LH surge, reached a maximum level of $205 \pm 90 \mathrm{pmol} / \mathrm{l}$ and declined gradually over $48 \mathrm{~h}$. This second oestradiol release lasted about 6 days. In one heifer no release of oestradiol after the LH surge occurred. 

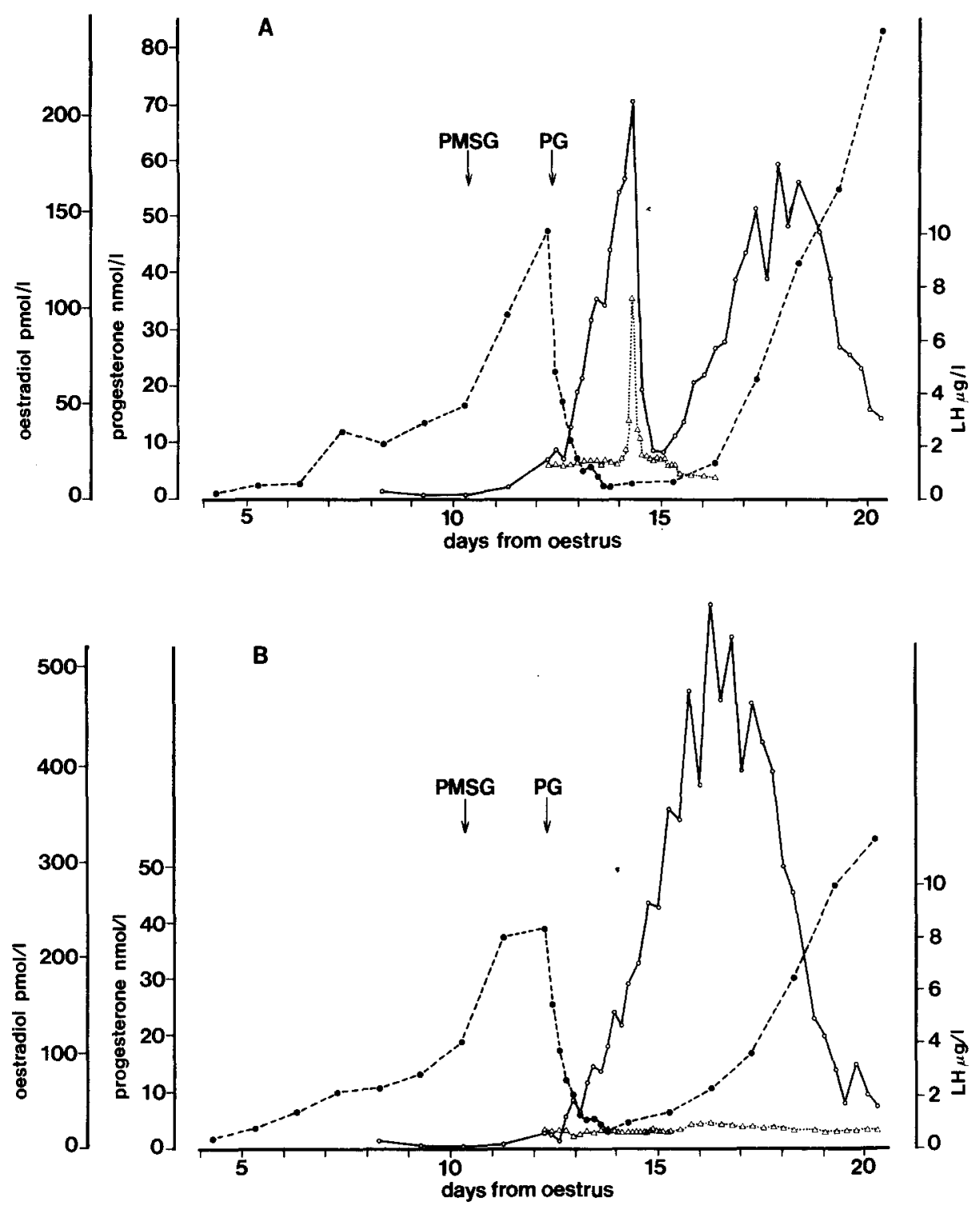

Fig. 1. Profiles of the levels of progesterone, oestradiol and LH in the peripheral blood of heifer 60 responding to PMSG/PG treatment with an $\mathrm{LH}$ surge (1A) and of heifer 64 not responding with an LH surge (1B). - - - , progesterone concentration (nmol/l); $\mathrm{O}-\mathrm{O}$, oestradiol concentration $(\mathrm{pmol} / \mathrm{l}) ; \Delta \cdots \Delta, \mathrm{LH}$ concentration $(\mu \mathrm{g} / \mathrm{l})$. The arrows indicate the i.m. injection of 2500 I.U. PMSG and $2 \mathrm{ml} \mathrm{PG.}$

Progesterone levels were significantly enhanced $(P<0.001)$ to $36.1 \pm 1.9$ $\mathrm{nmol} / \mathrm{l}(n=7)$ at $48 \mathrm{~h}$ after the PMSG injection compared to the preceding 48 $\mathrm{h}$ period $(18.2 \pm 1.3 \mathrm{nmol} / \mathrm{l})$. After $\mathrm{PG}$ administration the progesterone level 


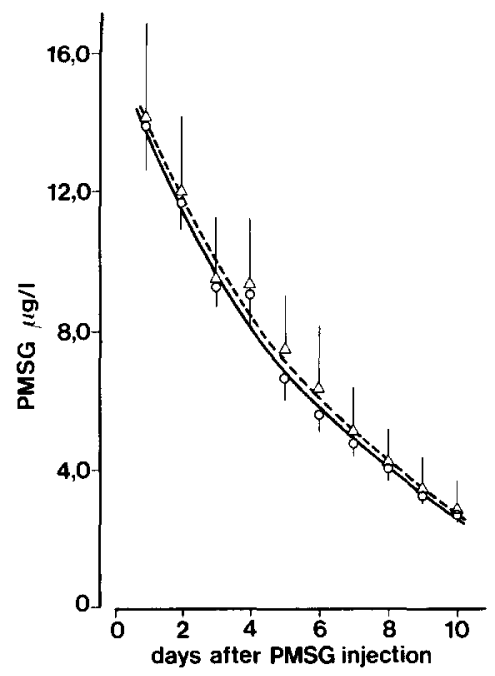

Fig. 2. Time course of the concentration of PMSG in the peripheral blood of heifers injected intramuscularly with 2500 I.U. PMSG; O-O, mean PMSG concentration ( \pm SEM; $n=7$ ) of the group of heifers with an LH surge; $\Delta-\cdots$ - - mean PMSG concentration ( \pm SEM; $n=3$ ) of the group of heifers without an LH surge.

declined and had a mean value of $3.69 \pm 0.41 \mathrm{nmol} / \mathrm{l}$ at the time of the occurrence of the LH surge. It increased thereafter in 5 heifers and at 6 days after the LH surge the concentration was $99.7 \pm 39.1 \mathrm{nmol} / \mathrm{l}$ in these cows. In 2 heifers no increase of progesterone occurred after the LH surge.

Group $B(n=3)$. In the three heifers in which no LH surge was detected, the oestradiol concentration increased steadily after PMSG injection to a maximum level of $464 \pm 143 \mathrm{pmol} / \mathrm{l}$; this maximum was reached about 6 days after PMSG administration and then decreased gradually over a period of about 48 h.

Progesterone levels were significantly $(P<0.01)$ enhanced to $44.2 \pm 3.1$ $\mathrm{nmol} / \mathrm{l}$ at $48 \mathrm{~h}$ after the $\mathrm{PMSG}$ injection compared to the preceding $48 \mathrm{~h}$ period $(23.1 \pm 1.8 \mathrm{nmol} / \mathrm{l})$. After PG administration the progesterone level declined and had a mean value of $5.63 \pm 1.14 \mathrm{nmol} / \mathrm{l}$ during a period similar to that in which the LH surge was measured in group A; this level was not significantly different from that of group A. Thereafter progesterone increased slowly in 2 heifers, and 8 days after the $P G$ administration the concentration was $51.1 \pm 4.8$ $\mathrm{nmol} / \mathrm{l}$. In one heifer no increase in progesterone occurred.

Fig.2 shows that the difference in hormonal response between group $A$ and B upon PMSG injection is not caused by a different starting level of this hormone in the peripheral blood or the time course of its degradation. Levels of prolactin and cortisol were determined in each heifer in the period from the 
TABLE 1

Mean prolactin and cortisol levels in the peripheral blood of heifers from the day of PMSG administration until 10 days after

\begin{tabular}{lll}
\hline $\begin{array}{l}\text { Group: } \\
\text { heifer }\end{array}$ & $\begin{array}{l}\text { Mean prolactin level } \\
(\mu \mathrm{g} / \mathrm{l} \pm \mathrm{SEM})\end{array}$ & $\begin{array}{l}\text { Mean cortisol level } \\
(\mathrm{nmol} / \mathrm{l} \pm \mathrm{SEM})\end{array}$ \\
\hline $\mathrm{A}: 55$ & $13.79 \pm 2.35$ & $25.82 \pm 8.86$ \\
59 & $16.32 \pm 2.59$ & $31.67 \pm 10.89$ \\
60 & $18.67 \pm 4.07$ & $31.70 \pm 9.35$ \\
68 & $11.51 \pm 1.55$ & $29.02 \pm 7.83$ \\
86 & $15.77 \pm 5.23$ & $26.07 \pm 5.57$ \\
281 & $19.67 \pm 3.95$ & $16.71 \pm 6.15$ \\
283 & $24.56 \pm 2.88$ & $25.27 \pm 6.92$ \\
Average of & & \\
the mean: & $17.18 \pm 1.61(n=7)$ & $26.62 \pm 1.93(n=7)$ \\
& & \\
B: 40 & $17.31 \pm 2.54$ & $33.46 \pm 5.66$ \\
43 & $15.36 \pm 3.29$ & $25.27 \pm 4.94$ \\
64 & $22.19 \pm 4.27$ & $17.55 \pm 4.88$ \\
Average of & & $25.43 \pm 4.60(n=3)$ \\
the mean: & $18.29 \pm 2.03(n=3)$ & \\
\hline
\end{tabular}

Group A; with an LH surge after PMSG/PG treatment.

Group B; without an LH surge after PMSG/PG treatment.

$n$; number of heifers.

The levels of prolactin and cortisol were estimated in the daily blood samples collected at $07.00 \mathrm{~h}$, i.e. 10 samples per heifer.

day of PMSG administration until 10 days thereafter. The mean concentrations of both hormones in each cow are presented in Table 1 together with the average of these means for groups $\mathrm{A}$ and $\mathrm{B}$. For prolactin as well as for cortisol there was no significant difference in the average of the means of groups $A$ and B.

\section{Experiment 2}

Four of the 32 heifers involved in this experiment had no detectable LH surge after PMSG/PG treatment. Three of them failed to show oestrous behaviour or standing oestrus while the fourth showed standing heat at $42.5 \mathrm{~h}$ after PG administration. Profiles of progesterone, oestradiol and LH were similar to those described in group $B$ of the first experiment. This means that in $16.7 \%$ of the heifers involved in both experiments, the LH surge failed to occur after stimulation of follicular growth with PMSG.

Data concerning the 28 heifers which responded to the PMSG/PG treatment with an LH surge are presented in Table 2. It appeared that PMSG administration caused a significant increase $(P<0.001)$ of the progesterone 
TABLE 2

Observations on 28 heifers treated with 2500 I.U. PMSG and PG on day 10 and day 12 of the oestrous cycle respectively

\begin{tabular}{|c|c|}
\hline & Mean value $\pm \operatorname{SEM}(n)$ \\
\hline $\begin{array}{l}\text { Progesterone level ( } \mathrm{nmol} / \mathrm{l}) \text { the day before } \\
\text { PMSG administration }\end{array}$ & $14.9 \pm 1.3(28)$ \\
\hline $\begin{array}{l}\text { Progesterone level }(\mathrm{nmol} / \mathrm{l}) \text { the day after } \\
\text { PMSG administration }\end{array}$ & $24.3 \pm 1.2$ \\
\hline $\begin{array}{l}\text { Progesterone level }(\mathrm{nmol} / \mathrm{l}) \text { at the maximum } \\
\text { of the LH surge }\end{array}$ & $1.56 \pm 0.13(27)$ \\
\hline $\begin{array}{l}\text { Oestradiol level (pmol/1) at the maximum of } \\
\text { the LH surge }\end{array}$ & $286 \pm 44$ \\
\hline Maximum level $(\mu \mathrm{g} / 1)$ of the LH surge & $13.5 \pm 1.0$ \\
\hline $\begin{array}{l}\text { Basal LH level }(\mu \mathrm{g} / \mathrm{l}) \text { in the } 4 \mathrm{~h} \text { period } \\
\text { preceding the } \mathrm{LH} \text { surge }\end{array}$ & $1.06 \pm 0.08(28)$ \\
\hline $\begin{array}{l}\text { PMSG level }(\mu \mathrm{g} / 1) 7 \mathrm{~h} \text { after PG } \\
\text { administration }\end{array}$ & $9.06 \pm 0.39(27)$ \\
\hline Number of preovulatory follicles & $15.4 \pm 1.6$ \\
\hline $\begin{array}{l}\text { Interval }(h) \text { between } P G \text { and the maximum } \\
\text { of the LH surge }\end{array}$ & $43.9 \pm 1.5$ \\
\hline $\begin{array}{l}\text { Interval }(h) \text { between } P G \text { and onset of } \\
\text { oestrus }\end{array}$ & $42.7 \pm 1.6(22)^{*}$ \\
\hline $\begin{array}{l}\text { Interval }(h) \text { between onset of oestrus and } \\
\text { the maximum of the LH surge }\end{array}$ & $2.0 \pm 0.5(22)^{*}$ \\
\hline
\end{tabular}

*Six heifers did not show a clear time of first standing oestrus.

concentration in the peripheral blood. Only one heifer had a lower progesterone level after PMSG administration than before. The progesterone level before PMSG injection and the level the day before PG injection were not significantly correlated with the number of preovulatory follicles (Fig. 3A and B) or with the interval PG-LH surge. Luteal regression, defined as the period between PG injection and the time that the progesterone level fell below 3.2 $\mathrm{nmol} / \mathrm{l}$, lasted $20.9 \pm 1.2 \mathrm{~h}(n=28)$. In 3 cows the progesterone level was slightly above $3.2 \mathrm{nmol} / \mathrm{l}$ during the $\mathrm{LH}$ surge.

The interval PG-LH surge was negatively correlated with the number of preovulatory follicles $(r=-0.483 ; P<0.01)$ (Fig. $3 \mathrm{C}$ ).

The oestradiol level during the preovulatory LH surge was positively correlated ( $r=0.732 ; P<0.01)$ with the number of preovulatory follicles (Fig. $3 \mathrm{D}$ ). The oestradiol level was not related to the maximum of the LH surge or to the basal LH levels preceding the surge. Although the heifers were intramuscularly injected with the same dose of PMSG, the estimations showed that there was quite a difference between heifers in the concentration of the hormone in the peripheral blood. However, the variation in the PMSG level did not correlate with the variation in the number of preovulatory follicles (Fig. $3 \mathrm{E}$ and $\mathrm{F}$ ), with 

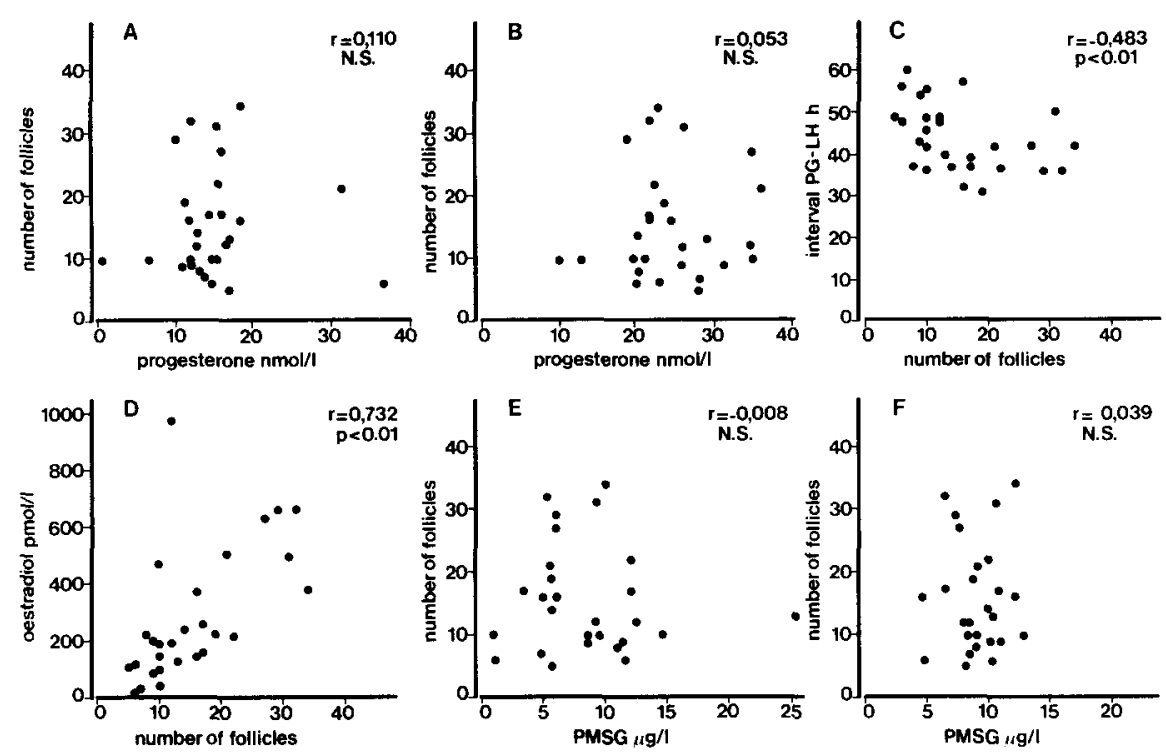

Fig. 3. Scatter plots of the correlations between the number of preovulatory follicles and:

$A$, the progesterone level on the day before PMSG administration.

$\mathrm{B}$, the progesterone level on the day after PMSG administration.

$\mathrm{C}$, the interval PG-LH surge.

$\mathrm{D}$, the oestradiol level during the $\mathrm{LH}$ surge.

$\mathrm{E}$, the PMSG level $7 \mathrm{~h}$ after PMSG administration.

$F$, the PMSG level $7 \mathrm{~h}$ after PG administration.

N.S. = non-significant.

the oestradiol peak level, with the interval PG-LH or with the progesterone level before PG administration. This was established for the PMSG level estimated at $7 \mathrm{~h}$ after the intramuscular injection of the hormone and for the PMSG level estimated at $7 \mathrm{~h}$ after the injection of $\mathrm{PG}$.

\section{DISCUSSION}

The patterns of progesterone, oestradiol and $\mathrm{LH}$ in the peripheral blood after stimulation of follicular growth with PMSG are in agreement with those reported by Saumande (1980). The endocrine responses can be divided into two groups. The main group, $83 \%$ of the heifers, demonstrated an endocrine profile until ovulation which differed from the profiles of normally cyclic cows during the follicular phase only in the time scale of the events and in the maximal levels reached (Dieleman et al., 1986). However, the other group, $17 \%$ of the heifers, is characterized by a lack of the preovulatory LH surge, indicating a dramatic perturbation of follicular development. A missing LH surge after PMSG treatment has previously been reported (Saumande, 1980; Jensen et al., 1982; Callesen et al., 1986). 
The rapid decline of the oestradiol concentration in the peripheral blood after the LH surge is consistent with previous observations concerning the oestrous cycle of non-stimulated heifers (Dieleman et al., 1986). The decrease is the result of the inhibition by the LH surge of the synthesis of androstenedione, which in the cow is the major substrate for the aromatase (Dieleman and Blankenstein, 1984). The more gradual decline of the oestradiol concentration, over a period of about $48 \mathrm{~h}$, noticed at the second oestradiol peak of group $A$ and at the peak of the group B heifers, probably reflects the process of atresia of the follicles involved in the oestradiol synthesis.

Elevated prolactin (McNeilly, 1980) or cortisol (Armstrong, 1986) may have inhibiting effects on gonadotrophin secretion. Prolactin and cortisol concentrations in heifers showing or not showing preovulatory LH surges were identical and similar to those previously reported for cyclic heifers (Dieleman et al., 1986), so variation in these hormones is not a major factor in the absence of an LH surge.

It can be concluded that intramuscular injection of PMSG results in differences in the rate of uptake of the drug in the peripheral blood, since a variable level of PMSG was observed between heifers. However, it appeared that the variation in PMSG levels was not related to the variation in response of heifers to the superovulation treatment. Lactating cows with a longer interval between the time of i.m. administration of 2500 I.U. PMSG and the maximum level of PMSG in the peripheral blood had a significantly greater number of large follicles (Yadav et al., 1986). Meinecke-Tillmann et al. (1987) reported a significant correlation between the PMSG levels and the recovery of a low $(<4)$ or high number $(>4)$ of corpora lutea after injection of 1000 I.U. PMSG into Merino ewes.

The finding that progesterone levels at the initiation of PMSG treatment and thereafter are not correlated with the number of preovulatory follicles agrees with previous reports on superovulation with PMSG and with FSH (Screenan and Gosling, 1977; Jensen et al., 1982; Tamboura et al., 1985; Lindsell et al., 1986). Contrary to this, Yadav et al. (1986) observed a significant correlation between the progesterone level at the initiation of superovulation treatment with FSH and PMSG and the ovulation rate in lactating cows ( $n=6$ for each group). Moreover, no increase in progesterone was observed after initiation compared to control cows.

The mean of the interval PG-LH surge of $43.9 \mathrm{~h}$ and its variation between animals upon PMSG/PG superovulation agrees with previous investigations regarding PMSG and FSH stimulation of follicular growth (Saumande, 1980; Jensen et al., 1982; Yadav et al., 1983; 1986; Callesen et al., 1986; Lindsell et al., 1986).

The time of onset of standing oestrus after PG presented in this paper was similar to that observed by Yadav et al. (1986). However, the interval of $2 \mathrm{~h}$ between onset of standing oestrus and the LH surge contrasted with the ob- 
servations of Yadav et al. (1986) and Jensen et al. (1982) that the LH surge precedes standing oestrus by about $3 \mathrm{~h}$ in PMSG-stimulated dairy cows and heifers.

The variation in the interval onset of oestrus to the maximum of the $\mathrm{LH}$ surge (range -2 to $+8 \mathrm{~h}$ ) agrees with the data from Greve et al. (1984). Since the interval LH surge to ovulation is important in connection with the final stages of follicular and oocyte maturation, using the preovulatory $\mathrm{LH}$ surge as reference for the optimal moment of insemination may increase the number of viable embryos. This supposition is further supported by the fact that a fair proportion of cows does not show a detectable LH surge or shows impaired oestrus behaviour which may be due to breed and season.

With regard to the three stages postulated in the introduction of this paper, it can be concluded that in the first stage, the period from the initiation of PMSG treatment until the PG injection, only the inherent variation of the follicle population contributes to the variation in the superovulation response. Progesterone and PMSG levels during this period are in this respect of no importance. It has been shown (Mariana and Nguyen Huy, 1973; Kruip, 1982) that the proportions of follicles in different classes vary throughout the cycle. Moor et al. (1984) supposed that the follicles that ovulated after gonadotrophin treatment were generally recruited from medium-sized, non-atretic follicles which were most abundant on days $0-5$ and $9-13$ of the oestrous cycle. Intraovarian regulation mechanisms are insufficiently known to eliminate inherent differences in follicle dynamics and to overcome thereby this primary source of variability during superovulation. The results of studies in which cows were pretreated with FSH in the early luteal phase to create a larger susceptible follicle population at the day of gonadotrophin treatment are contradictory (Lussier and Carruthers, 1987; Ware et al., 1987).

In the second stage, the period from the PG injection until the LH surge, normally (in non-treated cows) the selection and growth of the preovulatory follicle take place: from a growing cohort of follicles one follicle attains a state of dominance over the remaining follicles, inhibiting their growth rate. Its increasing secretory activity places it in control of both the pituitary and the other follicles in the cohort which ultimately become atretic (Spicer and Echternkamp, 1986).

In the superovulated cows the outstanding feature of the second stage is the shortening of this period and its variation between animals, which is correlated with the number of preovulatory follicles. The constantly elevated non-physiological level of gonadotrophins by the presence of PMSG rescues follicles from the process of atresia and thus enhances the number of preovulatory follicles (Monniaux et al., 1984; Moor et al., 1984). There is, however, a lack of knowledge on the impact of the observed acceleration of events reflected by the hormone patterns in this period. As the occurrence of the LH surge is the ultimate result of an interaction between the follicles and the hypotha- 
lamic-pituitary system, it can be argued whether the follicles have developed susceptibility to the LH surge at the time it occurs. On the other hand, the amplified hormone signal produced by the increased number of follicles may overrule every local regulation system at the level of the individual follicle, thereby causing abnormalities in the secretory activity in a part of them (Dieleman and Kruip, 1980).

In the third stage, the period from the preovulatory LH surge until ovulation, final follicular and oocyte maturation occur and these proceed according to a fixed hormonal pattern (Dieleman et al., 1983a). Aberrations in the maturation of the oocytes after superovulation with PMSG are reported by Callesen et al. (1986) and Hyttel et al. (1986). Treatment of heifers superovulated with PMSG with a monoclonal antibody raised against the hormone showed a twofold increase in the number of ovulations at $30 \mathrm{~h}$ after the LH surge (Dieleman et al., 1987). This observation strongly indicates that PMSG, which is still present after the LH surge, exerts a negative action on the final stages of folliculogenesis. How abnormalities in follicular growth and development are reflected in steroidogenesis, receptor binding and oocyte maturation, including the implications for the viability of embryos, is currently being investigated.

\section{ACKNOWLEDGEMENTS}

The authors wish to thank Mrs. D.M. Blankenstein, Mrs. H.T.M. van Tol and Mr. A.V.P. van de Poll for their technical assistance. Thanks are also due to Mr. S.H.J. Mook and co-workers for tending the animals and to Mr. W. Bes for drawing the figures. Sincere thanks to Intervet International B.V. for supplying the Folligon and Prosolvin and financially supporting the project. We thank the NIAMDD for supplying NIH-P-B3 and NIH-LH-B4, and Dr. K.W. Cheng, University of Manitoba, for the bovine FSH preparation.

\section{REFERENCES}

Armstrong, D.T., 1986. Environmental stress and ovarian function. Biol. Reprod., 34: 29-39.

Bouters, R., Moyaert, I., Corijn, M. and Vandeplassche, M., 1983. The use of a PMSG antiserum in superovulated cattle: endocrinological changes and effects on timing of ovulation. Zuchthygiene, 18: 172-177.

Callesen, H., Greve, T. and Hyttel, P., 1986. Preovulatory endocrinology and oocyte maturation in superovulated cattle. Theriogenology, 25: 71-86.

Cheng, K.W., 1978. Development and characterization of a homologous radioimmunoassay for bovine follicle stimulating hormone. J. Endocrinol., 77: 185-193.

Dieleman, S.J. and Blankenstein, D.M., 1984. Changes in oestrogen-synthesizing ability of preovulatory bovine follicles relative to the peak of LH. J. Reprod. Fertil., 72: 487-494.

Dieleman, S.J. and Blankenstein, D.M., 1985. Progesterone-synthesizing ability of preovulatory follicles of cows relative to the peak of LH. J. Reprod. Fertil., 75: 609-615.

Dieleman, S.J. and Kruip, Th.A.M., 1980. Relation between $3 \beta$-hydroxysteroid dehydrogenase 
activity in bovine preovulatory follicles and steroids present in the follicular fluid during nor-

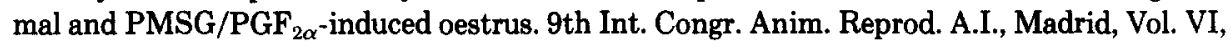
pp. 90-93.

Dieleman, S.J. and Schoenmakers, H.J.N., 1979. Radioimmunoassays to determine the presence of progesterone and estrone in the starfish Asterias rubens. Gen. Comp. Endocrinol., 39: 534-542.

Dieleman, S.J., Kruip, Th.A.M., Fontijne P., De Jong, W.H.R. and Van der Weyden, G.C., 1983a. Changes in oestradiol, progesterone and testosterone concentrations in follicular fluid and in the micromorphology of preovulatory bovine follicles relative to the peak of luteinizing hormone. J. Endocrinol., 97: 31-42.

Dieleman, S.J., Bevers, M.M., Poortman, J. and Van Tol, H.T.M., 1983b. Steroid and pituitary hormone concentrations in the fluid of preovulatory bovine follicles relative to the peak of $\mathrm{LH}$ in the peripheral blood. J. Reprod. Fertil., 69: 641-649.

Dieleman, S.J., Bevers, M.M., Van Tol, H.T.M. and Willemse, A.H., 1986. Peripheral plasma concentrations of oestradiol, progesterone, cortisol, $\mathrm{LH}$ and prolactin during the oestrous cycle in the cow, with emphasis on the peri-oestrous period. Anim. Reprod. Sci., 10: 275-292.

Dieleman, S.J., Bevers, M.M. and Gielen, J.Th., 1987. Increase of the number of ovulations in PMSG/PG treated cows by administration of monoclonal anti-PMSG shortly after the endogenous LH peak. Theriogenology, 27: 222.

Greve, T., Callesen, H. and Hyttel, P., 1984. Characterization of plasma LH profiles in superovulated dairy cows. Theriogenology, 21: 237.

Hyttel, P., Callesen, H. and Greve, T., 1986. Ultrastructural features of preovulatory oocyte maturation in superovulated cattle. J. Reprod. Fertil., 76: 645-656.

Jensen, A.M., Greve, T., Madej, A. and Edqvist, L.E., 1982. Endocrine profiles and embryo quality in the PMSG-PGF ${ }_{2 \alpha}$ treated cow. Theriogenology, 18: 33-44.

Kruip, Th.A.M., 1982. Macroscopic identification of tertiary follicles $>2 \mathrm{~mm}$ in the ovaries of cycling cows. In: H. Karg and E. Schallenberger (Editors), Factors Influencing Fertility in the Postpartum Cow. Martinus Nijhoff, The Hague, pp. 95-101.

Lindsell, C.E., Murphy, B.D. and Mapletoft, R.J., 1986. Superovulatory and endocrine responses in heifers treated with FSH-P at different stages of the estrous cycle. Theriogenology, 226: $209-221$.

Lussier, J.G. and Carruthers, T.D., 1987. Endocrine and superovulatory responses in heifers pretreated with FSH or follicular fluid. Theriogenology, 27: 253.

Mariana, J.C. and Nguyen Huy, 1973. Folliculogénèse chez la vache. Ann. Biol. Anim. Biochim. Biophys., 13: 211-221.

McNeilly, A.S., 1980. Prolactin and the control of gonadotrophin secretion in the female. J. Reprod. Fertil., 58: 537-549.

Meinecke-Tillmann, S., Evers, P. and Meinecke, B., 1987. Relationship between PMSG plasma concentrations and ovarian response after superovulatory treatment in Merino ewes. Theriogenology, 27: 259.

Monniaux, D., Mariana, J.C. and Gibson, W.R., 1984. Action of PMSG on follicular populations in the heifer. J. Reprod. Fertil., 70: 243-253.

Moor, R.M., Kruip, Th.A.M. and Green, D., 1984. Intraovarian control of folliculogenesis: limits to superovulation. Theriogenology 21: 103-116.

Reichert, L.E., 1975. Purification of anterior hormones. Methods Enzymol., 38: 360-381.

Saumande, J., 1980. Concentrations of luteinizing hormone, oestradiol-17 $\beta$ and progesterone in the plasma of heifers treated to induce superovulation. J. Endocrinol., 84: 425-437.

Screenan, J.M. and Gosling, J.P., 1977. The effect of cycle stage and plasma progesterone level on the induction of multiple ovulations in heifers. J. Reprod. Fertil., 50: 367-369.

Spicer, L.J. and Echternkamp, S.E, 1986. Ovarian follicular growth, function and turnover in cattle; a review. J. Anim. Sci., 62: 428-451.

Tamboura, D., Chupin, D. and Saumande, J., 1985. Superovulation in cows: a relationship be- 
tween progesterone secretion before ovulation and the quality of embryos. Anim. Reprod. Sci., 8: 327-334.

Ware, C.B., Northey, D.L. and First, N.L, 1987. Effect of administration of FSH at the beginning of the cycle on the subsequent response to superovulation treatment in heifers. Theriogenology, 27: 292.

Yadav, M., Leslie, K.E. and Walton, J.S., 1983. The timing of the preovulatory LH surge and embryo production in superovulated cows. Theriogenology, 19: 150.

Yadav, M.C., Walton, J.S. and Leslie, K.E., 1986. Plasma concentrations of luteinizing hormone and progesterone during superovulation of dairy cows using follicle stimulating hormone or pregnant mare serum gonadotrophin. Theriogenology, 26: 523-540. 